\title{
The Image of Confucius in Ezra Pound's "Chinese Cantos" (Cantos LII - LXI)
}

\author{
Alireza Farahbakhsh \\ Associate Professor In English Literature, University Of Guilan, Iran
}

\begin{abstract}
The purpose of the present paper is to take a close look at the image Ezra Pound portrays of Confucius in his Chinese Cantos (cantos LII - LXI), which he wrote in the 1930s. Focusing on Confucius's ideas on culture and economy, it studies Pound's reasons for his approval or disapproval of a number of Chinese emperors. The main concern of the paper is to realise how Confucius is pictured in the Chinese Cantos and what are the implications of his portrayal. The paper starts with a brief digest of Pound's views on economy, culture, banking systems, Douglas's Social Credit Theory, and war and proceeds to observe Confucian recommendations regarding peace and economic solidity in the selected cantos. The article shows that through condemning inefficient Chinese emperors and praising authoritative and competent rulers, Pound, in fact, is voicing his advocacy not only for the Chinese philosopher, but also for Italian fascism. In other words, in his Chinese Cantos, Pound extols Confucian views on agriculture, order, and administration with an eye on a leader he deemed to be the modern version of Confucius - Benito Mussolini.
\end{abstract}

Keywords: Culture, Economy, Social Credit Theory, Ideal Administration, Pound's Chinese Cantos

\section{Introduction}

Most of Pound's cantos were written between 1915 and 1962, although much of the early work was abandoned and the early cantos, as finally published, date from 1922 onwards. This modern epic is a book-length work, widely considered to present formidable difficulties to the reader. Strong claims have been made for it as one of the most significant works of modernist poetry of the twentieth century. Despite Pound's centrality in the modernist literature and the tremendous influence he exerted on his contemporary as well as future writers, in comparison with other men of letters of the early $20^{\text {th }}$ century, he has rather been unpopular. Hugh Kenner, the critic who advanced an understanding of Pound's work with his The Poetry of Ezra Pound, has asserted that "there is no great contemporary writer who is less read than Ezra Pound" $(1985,16)$. Carroll F. Terrell attributes the causes of Pound's unpopularity and the cold reception of his Cantos to his support for fascism, late arrival of literary criticism on The Cantos, and the difficulty of the text itself (1993, ix).

As in Pound's prose writing, the themes of economics, politics, and culture are integral to its content. In his Cantos, Pound seems to be openly concerned not only with contemporary cultural decay, but with the possible sources of cultural renewal. Pound's poetic imagination embraces multifarious examples of humanity and multiple ideas of order set by both eastern and western economists and politicians. There is a quest at the basis of Pound's Cantos which, as Pound suggests now and again, is reminiscent of Odysseus's ten-year quest in search of his home. The significant difference, however, is that Pound's quest is unending; it involves man's perpetual search for civilisation and order. In his Guide to Kulchur, Pound, as an activist and a reformer, insists on "ideas which are intended to go into action" or "to guide action and serve as rules (and/or measures) of conduct" (1952, 34). Concerning the quest motif in Pound's Cantos, Richard Gray has written:
The content of the Cantos stretches out far and wide, in pursuit of appropriate models of language, thought, and conduct, taking in, among many others, the Provencal and early Italian poets, founders of modes of government and codes of behaviour like Confucius and Jefferson, and some of the examples of primitive religious feeling recorded in Ovid's Metamorphoses." (1990, 79)

World War I, as Pound saw it, had been caused by the rivalries of international capitalists. He thought he had found a solution to the evils of unchecked capitalism, one especially favourable to the arts, in Confucius and in the Social Credit theory of Major C. H. Douglas (a $20^{\text {th }}$ century Scottish engineer), who argued that a system of state credit could increase purchasing power in the population at large, thus promoting creativity and removing power from bankers and financiers.

According to Hugh Witemeyer, like Douglas, Pound came to the conclusion that poverty and war result from the inequitable distribution of consumer purchasing power in a capitalist economy. What distorts an ideal distribution of purchasing power is the control of credit by private banks as well as the charging of exorbitant interest or usury for the use of credit; that is why there is no end to poverty and war if credit is not nationalised in the public interest $(1969,167)$. Attracted to Mussolini by his energy and his promises of monetary reform, Pound naïvely assumed that the Italian leader could be persuaded to put Douglas's theory into practice. In his Ezra Pound: A Literary Life, Ira B. Nadel has commented that

Much of Mussolini's appeal lay in what Pound understood as his progressive monetary policies. His political instincts made him a modern Jefferson, his economic intuitions an authentic Social Credit practitioner who believed in the theory of the Just Price. Pound favored Mussolini's plans for corporative assemblies, land reclamation and the reevaluation of currency. He also believed that Italian fascism was committed to breaking the stranglehold of international 


\section{International Journal of Science and Research (IJSR) \\ ISSN (Online): 2319-7064}

Index Copernicus Value (2013): 6.14 | Impact Factor (2015): 6.391

banking which he held responsible for the creation of wars. (2004, 133-34)

In the same vein, William Sievert has written that Mussolini's stunning success in rebuilding Italy convinced Pound that fascist economic and political guidelines could eventually result in welfare and peace and prevent the outbreak of another international war $(1965,19)$. At first, the main target of Pound's attacks is 'usury,' which he depicts (e.g. in Canto XLV - "With Usura") as an unnatural force that pollutes the creative instinct in humanity. Commenting on Pound's conception of 'usury,' Kearns explains that "Pound is less concerned with quibbles over interest rates than with the perversion of use - of a man's time, of the fruits of the earth" $(1989,122)$. In his The Genesis of Ezra Pound's Cantos, Ronald Bush asserts that Pound "condemns usury not simply because it interferes with an artist's creation, but because it perverts the bounty and sustenance of God's art, which is nature" $(1976,134)$. By about 1930 , however, the usurers he condemns are usually Jewish, and his language is vitiated by virulent anti-Semitism. In his The Genealogy of Demons: Anti-Semitism, Fascism, and the Myths of Ezra Pound, Robert Casillo argues that

While Pound is by no means hostile to all forms of money, he obsessively attacks that form of it - namely usury - which he thinks the Jews created ... He believes implicitly that the Jews, for whom labor is "the curse of Adam," reject the principle of work. The usurers, in Pound's view, are against the natural increase of agriculture or of any productive work. $(1988,216)$

In Pound's view, the reasons for the outbreak of World War I were to be sought in economic systems; therefore, economic reform was the only way to prevent a second international war. That is why Pound occupied himself with studying various economic books and essays. He read Marx's Kapital, too, and admired his passion for social justice, but came to the conclusion that Marx never properly understood the nature of money. Obviously, Marx's classless society had no place in Pound's fascist ideology. Douglas, on the other hand, had rightly diagnosed the principal problems that caused economic setbacks. Elaborating on Douglas's economic standpoint in The Cambridge Companion to Ezra Pound, Ira B. Nadel writes: "C. H. Douglas ... sought to correct the inequitable distribution of wealth, purchasing power and credit. The control and exploitation of credit by private banks was for Douglas - and soon for Pound - the main culprit" (1999, 10). The dominant and orthodox economic notion that money needed to be backed by gold, unlike Douglas's premise, locked the industrial nations of his time in a fierce competition for foreign markets and made war an inevitable solution. Criticising the contemporary orthodox monetary system in his canto XII, Pound writes:

And C. H. [Douglas] said to the renowned Mr. Bukos:

"What is the cause of the $\mathrm{H}[$ igh] C[ost] of L[iving]?" and Mr, Bukos,

The economist consulted of nations, said: "Lack of labour."

And there were two millions of men out of work ..
I went on plaguing Mr. Bukos

Who said finally: "I am an orthodox

Economist." (1996, 108)

In the 1930s, in addition to Douglas's Social Credit doctrine, the writings of Confucius exerted a long-lived impact on Pound's political and economic thought. Pound had first become interested in Chinese poetry through Ernest Fenollosa's translations in the early 1910s, and for fifty years he continued to work as a student and a translator of Chinese language. Tim Redman has explained that

During the period of the late 1930s and particularly during the Second World War, Pound became convinced that the philosophy of Confucius, along with the economic reform, offered the best hope for an enduring and just social order, and he worked to translate Confucius into Italian and publish his work in Italy. $(1991,126)$

Pound held that Europe could flourish again under Confucian cultural, moral, and economic principles. Pound was fascinated by Confucius's emphasis on harmony, peace, simplicity, and order. In canto XIII, Pound writes that according to Confucius ("Kung"), "If a man have not order within him / He can not spread order about him" (1996, 58). In his diagnosis of the corruption of culture caused by usury and flawed banking systems, Pound returns to the values of Confucian thought. Confucius, who set about to promote social order from a rational and practical, rather than an abstract or idealistic, perspective, is one of the first names one comes across in Pound's Cantos. As early as the 1920s, Pound started his research into economics, and soon he was attracted to such figures as Confucius, one of the first monetary thinkers in history, and Douglas. He held that their prescriptions for reform could eventually rescue Europe from cultural and economic decay which was threatening its prosperity.

The present paper aims to introduce Pound's monetary philosophy and trace Confucius's economic views in a number of his 1930 s cantos. It must be noted that Pound's economic and political ideologies are so closely interconnected that one cannot discuss either of them independently of the other. However, the present study focuses on economic and monetary rather than political and governmental issues. The selected cantos for the discussion on Pound's criticism of contemporary banking systems and his views on Confucius are cantos LII - LXI (better known as Chinese Cantos). Douglas's economic views are also traced in these series of cantos since Pound has imbedded in them a number of references to his monetary recommendations.

\section{Discussion}

Cantos LII-LXI of the Chinese Cantos are based on the first eleven volumes of the twelve-volume Histoire generale de la Chine by Joseph-Anna-Marie de Moyriac de Mailla (volume 12 being an index). De Mailla was a French Jesuit who spent 37 years in Peking and wrote his history there. The work was completed in 1730 but not published until 1777. De Mailla, as his view of Chinese history reflects, was very much an Enlightenment figure. Pound found Confucian 


\section{International Journal of Science and Research (IJSR) \\ ISSN (Online): 2319-7064 \\ Index Copernicus Value (2013): 6.14 | Impact Factor (2015): 6.391}

economic and political philosophy, with its emphasis on rational order, very much to his liking. He also disliked what he saw as the superstitious pseudo-mysticism promulgated by both Buddhists and Taoists for he was of the opinion that its passivity posed a threat on pragmatic and rational politics. Pound translated de Mailla's conception of China into his own views on Christianity and on the need for a strong leader to address $20^{\text {th }}$ century fiscal and cultural problems - a figure like Mussolini. In an introductory note to his Chinese Cantos, Pound states that the ideograms and other fragments of foreign language texts incorporated in Chinese Cantos, and in The Cantos in general, should not put the reader off as they serve to underline things that are in the English text and what is to be taken into account is the overall impression.

Pound advocated Confucian thought and pragmatic politics in his Chinese Cantos to show his resistance to what he regarded as the debasement of human life within the contemporary conditions of bourgeois economics - the condition of capitalism, which distorted the nature and purpose of work, time, and wealth. The emphasis of the historical materials in the Chinese Cantos is not on the past but on the present. Put another way, Pound has tried to reflect the merits and demerits of various Chinese dynasties in order to warn the present politicians and economists against the detrimental effects of excessive taxation, usury, and chaos. As he contends in canto LIV, "History is a school-book for Princes."

In his Guide to Kulchur, Pound remarks that "Kung [Confucius] is modern in his interest in folk-lore," in his concern with "the living" rather than with "the dead," and in his stress on direct knowledge and personal experience, which could be obtained through travelling and commerce, and be used as a "good antidote for theories" or abstraction. All these aspects of Confucius appear to Pound "to be in conformity with the best modern views" (1952, 272-74). When Pound contemplated Kung, it was by means of comparison that he grasped the parallels between ancient and modern, East and West. To Pound, the history of Confucius bore so many affinities to what he sought amidst his own realities that he regarded him as a potent 'modern' reformer. Here we can see clearly how Pound bridges the past and the present by means of comparison.

Chinese Cantos introduce the foundations for a sound and productive economic management and the right form of government; also, as Philip Furia has argued, they transmit authority and preserve law from tyranny or personal prejudice $(1984,8)$. Labour in these cantos becomes associated with seasonal time, natural order, and freedom from tyranny. Pound's ideal empire is an "empire of laws not of men" (canto LXVII) and such laws are not bent to "wanton imagination" or to the "temper of individuals" (canto LXII). The Confucian temperament Pound reflects in his Chinese Cantos is representative and expressive of a hierarchy based on authority and knowledge; as he writes in canto LVI, "No slouch ever founded a dynasty." In the Chinese Cantos, Pound praises those emperors who, following Confucian economic and cultural instructions, contributed to the economic solidity of their nation. They halved the taxes to "let the farm folk have tools for their labour," "unjailed" 300 prisoners so that they could "do their spring ploughing," and refrained from locking up "the people's subsistence" (LIV). These instructions, included in the first part of the Chinese Cantos, are studied more closely in the following passages.

Canto LII opens with references to Duke Leopoldo, John Adams and Gertrude Bell, before sliding into a particularly virulent anti-Semitic passage, directed mainly at the Rothschild family. The remainder of the canto is concerned with the classic Chinese text known as the Li Ki or Book of Rites, especially the parts that deal with agriculture and natural increase. The diction is similar to that of earlier cantos on similar subjects. The $L i K i$ offers a clear model for the Confucian measurements of value by task as opposed to time. What matters here, as Wendy Stallard Flory has suggested, is not the seasonal cycle in its temporal sense but the sense of the particular appropriateness of particular tasks organised by the accompanying rites $(1980,163)$. The canto distinguishes organic or natural from mechanical time and underscores man's bond with the "vita universe" and the need to respect "the times and seasons." As William Cookson has commented, canto LII runs from the beginning of the summer to the end of the winter, forming a natural overture to the long chronicle of Chinese history $(2001,73)$. The tranquility of nature and Confucian instructions on natural work, which are the central issues of many of the passages in canto LII, are discernible in the following excerpt:

Cut trees at solstice, and arrow shafts of bamboo.

Third month, wild geese go north, magpie starts building,

Pheasant lifteth his voice to the Spirit of Mountains The fishing season is open, rivers and lakes frozen deep

Put now ice in your ice-house, the great concert of winds Call things by the name. $(1996,271)$

Canto LIII covers the period from the start of the Hai dynasty to the life of Confucius and up to circa 225 BC. Especial mention is made of emperors whom Confucius approved of; also, Confucius's interest in cultural matters is stressed. For example, we are told that he edited the Book of Odes, cutting it from 3000 to 300 poems. Moreover, the canto ascribes the Poundian motto (and title of a 1934 collection of essays) Make it New to the Emperor Tching Tang who "kept down the taxes" and "kept lynx eye on bureaucrats / lynx eyes on the currency" (277). Confucius's (and Pound's) favourite emperors understood that values were not to be viewed as materilised labour and that economic activity, the source of wealth, could be tainted by usury. They held that if people limited their concern to amassing money they would repress natural wealth and productivity. They all spoke "evil of taxes," kept "the peace," and cared "for the people." Among other emperors Pound praises is Chao-Kong:

Honour to Chao-Kong the surveyor. Let his name last 3000 years

Gave each man land for his labour not by plough-land alone 


\section{International Journal of Science and Research (IJSR) \\ ISSN (Online): 2319-7064 \\ Index Copernicus Value (2013): 6.14 | Impact Factor (2015): 6.391}

But for keeping of silk-worms

Reforested the mulberry groves

Set periodical markets

Exchange brought abundance, the prisons were empty ...

Peace and abundance bring virtue. (278-79)

Canto LIV moves Chinese history on to around 805 AD. The line "Some cook, some do not cook, / some things can not be changed" refers to Pound's domestic life and recurs, in part, in Canto LXXXI. Like other Chinese cantos, canto LIV deals with methods of economics and shows a composite picture of an ideal ruler and administrator who is sensitive to the needs of his people and speaks "evil of" taxes and usury. Peter Makin explains that Confucius's (as well as Pound's) recommended ruler

[f]ights the ever-recurring tendency towards graft; he cuts past his institutional advisors, to communicate with the ordinary man; he considers war, hunting across farmland by courtiers, palace extravagance, first and foremost as oppressions. He reverences God and the firtility-spirits in ploughing the annual furrow. His constructive energy cannot be defeated by endless obstacles ... he has a sense of the creative group working together, and ... is aware of the suffering of the men under his command. $(1985,219)$

One such ruler, according to Pound, is Emperor HIAO OUEN TI who wrote:

Earth is the nurse of all men

I now cut off one half the taxes

I wish to follow the sages, to honour Chang Ti by my furrow

Let farm folk have tools for their labour it is for this I reduce the said taxes

Gold is inedible. Let no war find us unready.

Thus Tchao-tso of his ministry (war)

'Gold will sustain no man's life nor will diamonds keep the land under culture ...

by wise circulation. (289)

In his Chinese cantos, and through his descriptions of his ideal ruler, Pound seems to implicitly voice his support for Mussolini. He brings out of China a doctrine of rebellion against the contemporary political and economic systems and a recommendation of his favourite ruler. Mussolini, Pound argued, had a sense of the people's pulse because he came from among them; also, he was a fighter of oppression and a promoter of agriculture. Thus, in his Chinese Cantos, Pound was not simply portraying the tranquility of nature or reflecting Confucian cultural views or ideal rulers; he was, in effect, introducing his desired ruler and political systems. This is how, as Pound's critics have contended, politics and economics always go hand in hand in every passage of Pound's Cantos, ultimately to introduce Mussolini as a saviour.

Canto LV is mainly concerned with the rise of the Tartars and the Tartar Wars that ended about 1200. There are quite a few monetary policies in the canto and Pound once again praises Confucius whom here he describes as "the master of emperors." Elaborating on Pound' conception of money,
Peter Nicholls writes that for Pound, it is "the instrument of productive activity" (1984, 75). Many passages teach circulation of abundance and distribution, backed by a money handout in times of trouble. One of the emperors Pound pays tribute to is Ngan who was in favour of a "just price" fixed by the state:

and at this time began Ngan

... to demand that they reset the market tribunals,

posting every day what was on sale and what the right price of it... (309)

Ngan ordered these markets to be monitored by the government and taxed lightly,

thereby relieving the poor of all douances [customs]

giving them easy market for merchandise and enlivening commerce

by making to circulate the whole realm's abundance. (309)

This is Pound's ideal state intervention; it encourages productivity and creativity and curbs usury. Ngan fought poverty and unemployment through direct and timely state support and so his nation survived famine:

And Ngan saw land lying barren

because peasants had nowt to sow there whence said: Lend 'em grain in the spring time that they can pay back in autumn with a bit of an increase, this wd/ augment the reserve. (309)

As for the currency, Ngan tried his best to control inflation and upkeep the value of money and made sure that there was always enough money in circulation:

$$
\begin{aligned}
& \text { Ngan made yet a third point } \\
& \text { that was to fix the value of money } \\
& \text { and to coin enough denars } \\
& \text { that shd/ stay always on the same footing. (310) }
\end{aligned}
$$

What threatened Ngan's state was the inflexibility and greed of the mandarins (usurpers) who oppressed "peasants to get back their grain loans." However, against this and similar financial challenges, his economic and political theories, which were meticulously put into effect, proved beneficial and he "worked 20 years."

Canto LVI opens with passages on war ("easy to start a war / not easy to finish one") and taxation ("SUNG died of levying taxes"). Like other Chinese Cantos, Pound here sets real wealth (productivity and seasonal work) against worldy possessions ("gold and jade are inedible"). This canto is mainly concerned with Ghengis and Kublai Khan and the rise of their Yeun dynasty. The canto closes with the overthrow of the Yeun and the establishment of the Ming dynasty, bringing us up to approximately 1400. As elsewhere, Pound catalogues righteous Chinese emperors, who showed no sympathy with usury and excessive taxing, and names their virtues. Yu, for instance, supervised bridge and road building and "gave grain to the people / kept down the taxes." Mengko, another 'Confucian' ruler,

\section{Volume 5 Issue 6, June 2016 www.ijsr.net}




\section{International Journal of Science and Research (IJSR) \\ ISSN (Online): 2319-7064}

Index Copernicus Value (2013): 6.14 | Impact Factor (2015): 6.391

took off taxes

And in Cai Fong they made a grain dividend and gave instruction in farming

ploughs, money, ammassi [grain reserves] ...

The word 'dividend' in the extract is reminiscent of Douglas's Social Credit theory. Pound's favoured ruler not only refrains from taxing people, but also offers money handouts (here in form of grain supply) to his people. Another such administrator is Han who

came from the people

How many fathers and husbands are fallen

Make census

Give rice to their families

Give them money for rites

Let rich folk keep their goods by them

Let the poor be provided

I came not against YUEN

but against grafters [usurers] and rebels ... (322)

On the other hand, there are emperors whose inefficiency eventually ruins the nation:

War scares interrupt commerce. Money was now made of brass

and profit on arms went to the government

wine taxed high, settlers licensed.

Lou-chi brought back the grafters

and boosted the tea tax ... (317-18)

Canto LVII, which like the rest of the Chinese Cantos is comparatively short, opens with the story of the flight of the emperor Kien Ouen Ti in 1402 or 1403 and continues with the history of the Ming up to the middle of the 16th century. Pound here expresses his vehement fury against hoarders and usurers whom he calls "eunuchs" because of the unproductivity and barrenness they spawn in the state: "And 8 bloody eunuchs conspired with Lieu, / thunderbolt fell, naturally, on the palace" (328).

Canto LVIII opens with a condensed history of Japan from the legendary first emperor Jimmu, who supposedly ruled in the 7th century BC, to Toyotomi Hideyoshi (Anglicised by Pound as Messier Undertree), who issued edicts against Christianity and raided Korea in the late 16th century, thus putting pressure on China's eastern borders. The canto then goes on to outline the concurrent pressure placed on China's western borders by activities associated with the great Tartar horse fairs, leading to the rise of the tartar Manchu dynasty. Manchu, a Poundian/Confucian ruler, adopted Chinese law and improved education. Commenting on the canto, Peter Makin explains that Manchu disparages fabrication, teaches loyalty, acts with restraint, and aims only to end oppression (1985, 220). In a letter to Emperor Ming, Manchu writes: "We took arms against oppression / and from fear of oppression / not that we wish to rule over you" (333). He does his utmost to maintain peace with other nations: "we have come for Peace not for payment. Come to bring peace to the Empire" (337). And to the governor of Suen-hoa-fou he writes: you are, indeed, subjects of a great realm

but the larger than empire, the more shd/ it strive toward peace

If children are cut off from parents

if wives can not see their husbands

if yr houses are devast and your riches carried away

this is not of me but of mandarins ... (335)

To pay homage to Manchu, the peace keeper, Pound concludes canto LVIII with a Chinese ideogram which stands for 'peace.' The translation of the Confucian classics into Manchu opens the following canto, Canto LIX. The canto is then concerned with the increasing European interest in China, as evidenced by a Sino-Russian border treaty and the foundation of the Jesuit Mission in 1685 under Jean-François Gerbillon. There are passages that reflect Confucian instructions on culture and personal conduct:

Urbanity in externals, virtu in internals some in a high style for the rites some in humble; for Emperors; for the people

all things are here brought to precisions that we shd/ learn our integrity

that we shd/ attain our integrity. (339)

"Eunuchs" are once again condemned and forced to give up their jobs:

And the four regents put eunuchs out of high office a thousand purged out of palaces and a half ton block of iron inscribed

Let there be no Eunuch in office hereafter. (341)

Canto LX deals with the activities of the Jesuits, who, we are told, introduced astronomy, western music, and physics (So the Jesuits brought in astronomy / ... music and physics from Europe"). The canto ends with limitations being placed on Christians ("barbarians"), who had come to be seen as enemies of the state. The Confucian values of order and natural work are once again celebrated:

Ortes very orderly, have lost none of their mongol habits,

their princes in concord, no usury.

Clever especially in lookin' after their animals, clumsy bowmen, but hit their mark. (345)

The final canto in the sequence, Canto LXI, covers the reigns of Yong Tching and Kien Long, bringing the story up to the end of de Mailla's account. Yong Tching is shown banning Christianity as "immoral" since he sees Christians (whom he describes as "hypocrites" and "sliders and liars") as people who seek to "uproot Kung's [Confucius'] laws." He also established just prices for foodstuffs, bringing us back to the ideas of Social Credit:

At moderate price we can sell in the spring to keep the market price decent And still bring in a small revenue which should be used to getting more next crop AMMASSI or sane collection, to have bigger provision next year, that is, augment our famine reserve and thus to keep the rice fresh in the store house.

Volume 5 Issue 6, June 2016 www.ijsr.net 


\section{International Journal of Science and Research (IJSR) \\ ISSN (Online): 2319-7064}

Index Copernicus Value (2013): 6.14 | Impact Factor (2015): 6.391

There are also references to the Italian Risorgimento, John Adams, and Dom Metello de Souza, who gained some measure of relief for the Jesuit Mission. Pound, in Confucian terms, reiterates that unavoidable consequences of "grafting" and excessive taxing are war, inflation, and nonproductivity.

\section{Conclusion}

As observed, in the fist part of his Chinese Cantos (cantos LII-LXI), Pound expresses his views on culture and economics through focusing on one of his favourite figures in history - Confucius. This series of cantos offers a harmony between nature and man. Pound here bitterly criticises taxation, flawed monetary policies, war, and usury and praises those emperors who followed Confucius's footsteps and stood up against economic and cultural corruption. Peter Makin explains that

Chinese common sense even of the most ancient periods arrived at an understanding of the relations between man and nature and suggested economic programmes identical with those of modern men of sense. China understood that good government occurs when rulers or administrators keep open their communications and sense of identity with the people. Likewise, that when collective inhumanity and greed has brought decay in the state, energy must step in in whatever form is felt to be apt for the moment. $(1985,213)$

In addition to warmongers, usurers, and tax collectors, Pound reprimands such abstract and passive thinkers as Buddhists and Taoists. Pound insists on the necessity of strenuous practicality and lashes out all forms of sensuality and abstraction; he argues that a turbulent time needs authority and order rather than obscurantism (an assertion which seems Hobbsian in nature). In their frivolity and irresponsibility, Buddhists and Taoists, in effect, commit intellectual crime and drive nations to chaos. As Pound has written in his canto LIV, "The highbrows are full of themselves / learned, gay and irrelevant / on such base nothing stands" (290). On the other hand, there are 'Confucian' rulers who are aware of the needs of their people, denounce oppression, keep peace, control taxation, and rule with authority and integrity. In his Chinese Cantos, Pound seems to be strongly suggesting that his ideal ruler in the modern world is the Italian Duce, Benito Mussolini. It implies that he is inviting us to look through the image of Confucius to see that of - and identify it with - Mussolini's. That is why in reading Chinese Cantos, and in fact The Cantos as a whole, one can easily observe Pound's obsession with fascism - an obsession for which in 1945 he was indicted for treason and committed to St. Elizabeths Hospital for the Criminally Insane, Washington, D. C., where he stayed for the next twelve and a half years and which led to his disillusionment and deep regret in the last decades of his life.

\section{References}

[1] Bush, Ronald. The Genesis of Ezra Pound's Cantos. Princeton: Princeton University Press, 1976.
[2] Casillo, Robert. The Genealogy of Demons: AntiSemitism, Fascism, and the Myths of Ezra Pound. Evanston: Northwestern University Press, 1988.

[3] Cookson, William. A Guide to the Cantos of Ezra Pound. New York: Persea Books, 2001.

[4] Flory, Wendy Stallard. Ezra Pound and The Cantos: A Record of Struggle. New Haven: Yale University Press, 1980.

[5] Furia, Philip. Pound's Cantos Declassified. London: Pennsylvania State University Press, 1984.

[6] Gray, Richard. American Poetry of the Twentieth Century. London: Longman, 1990.

[7] Kearns, George. Guide to Ezra Pound's Selected Cantos. Cambridge: Cambridge University Press, 1989.

[8] Kenner, Hugh. The Poetry of Ezra Pound. Lincoln: The University of Nebraska Press, 1985.

[9] Makin, Peter. Pound's Cantos. London: George Allen and Unwin, 1985.

[10] Nadel, Ira B., ed. The Cambridge Companion to Ezra Pound. Cambridge: Cambridge University Press, 1999.

[11]__ Ezra Pound: A Literary Life. Hampshire: Macmillan, 2004.

[12] Nicholls, Peter. Ezra Pound, Politics, Economics and Writing. London: Macmillan, 1984.

[13] Pound, Ezra. Guide to Kulchur. London: Peter Owen, 1952.

[14]__. The Cantos of Ezra Pound. New York: New Directions, 1996.

[15]Redman, Tim. Ezra Pound and Italian Fascism. Cambridge: Cambridge University Press, 1991.

[16] Sievert, William. The Poetry of Ezra Pound. New York: Monarch Press, 1965.

[17] Terrell, Carroll F. A. Companion to the Cantos of Ezra Pound. Berkeley: The University of California Press, 1993.

[18] Witemeyer, Hugh. The Poetry of Ezra Pound: Forms and Renewal, 1908-1920. Berkeley: University of California Press, 1969. 